\title{
Principals' Climate Change Supportive Administrative Services for Effective Classroom Management in Public and Private Secondary Schools in Anambra State
}

\author{
Okoye, Chinasa Regina (Mrs.) \& Prof. A. S. Omenyi \\ Department of Educational Management and Policy, Nnamdi Azikiwe University, Awka, Anambra State, Nigeria
}

\begin{abstract}
The purpose of this study is to analyse the climate change supportive administrative services provided by principals for effective classroom management in public and private secondary schools in Anambra State. The area of this study is Anambra state and the descriptive survey research design was used. There are six education zones namely Aguata, Awka, Nnewi, Ogidi, Onitsha, and Otuocha education zones. The population for this study comprised 15,990 respondents made up of 6,293 teachers in the 256 public secondary schools and 9,697 teachers in the 481 registered private secondary schools in Anambra state. The sample size for this study is 852 teachers. The instrument for data collection is a structured questionnaire developed by the researchers. The questionnaire was subjected to face validation using three experts who are lecturers. The reliability of the instrument was established using 100 teachers $(50$ in private secondary schools and 50 in public secondary schools) in 20 secondary schools in Enugu state. Cronbach alpha method was used to determine reliability of the items because the instrument is homogeneously structured. The reliability coefficient of the instrument was 0.74 . The instrument was administered on the respondents directly by the researchers with the help of eight research assistants who are teachers in the various schools sampled. All the 852 copies of the questionnaire were correctly filled and retrieved. They were collated and subjected to statistical analysis. Data collected were analyzed using mean ratings to answer the research questions and $t-$ test to test the hypotheses at 0.05 level of significance. Finding indicated that, in public secondary schools, special school wears during extreme cold weather, proper sanitation and basing school hours on the dictates of the weather, are not provided as part of climate change supportive administrative services for classroom management. It was among others recommended that the government should not only organize workshops for secondary schools on climate change supportive administrative services, the private schools should be provided with waste collectors while the private schools should maintain the provided facilities.
\end{abstract}

Keywords:- Climate change; supportive administration; administrative services; climate change supportive administrative services; principal; effective classroom management; public and private secondary school.

\section{INTRODUCTION}

The classroom teachers are at the centre of the classroom activities because they are the ones who turn various educational policies into practice under a classroom setting. To ensure that quality education is provided to the students, classroom teachers are expected to manage the classroom effectively. This is because the classroom is where the actual teaching and learning activities take place and where all the educational policies and programmes are implemented.

According to Kyriacou (2005) the classroom is the meeting point for both teachers and students where curricular activities are implemented. The classroom is essentially the focal point for educational instruction and as such should be an environment conducive to quality teaching and learning. The extent to which this is achieved greatly depends on how the classroom is being managed.

Classroom management comes into play when a teacher tactfully directs students' activities, available educational resources and time constraint in such a way that the desired objectives are achieved. The points above have earlier been expressed by authorities, for example, classroom management, according to Froyen and Iverson (1999), focuses on three major domains; content, conduct and covenant management. Content management occurs when teachers manage space, materials, equipment, movement of people and lessons that are part of a curriculum or programme of studies. Conduct management refers to the set of procedural skills teachers employ in their attempt to address and resolve disciplinary problems in the classroom. Covenant management focuses on the classroom group as a social system that has its own features that teachers have to take into account when managing interpersonal relationships in the classroom. The three major components are essential in ensuring effective classroom management (Ajayi, 2010). 
A classroom that is not well managed may create a school climate where some teachers will become quite apathetic to school in general and more specifically to the quality and impact of their teaching. Students and teachers therefore need to be in a teaching- learning environment where they are not threatened, constantly interrupted by skirmishes and where students show keen interest and are attentive to what is happening in their classrooms. In this regard, the classroom teacher needs supportive administrative services from the school principal. These supportive administrative services are necessary since a number of factors within the school affect teachers' classroom management. This study focused on climate change supportive administrative services.

Climate change supportive administrative services are those services provided by school administrators towards helping the teachers to effectively manage their classroom in the face of extreme weather conditions. According to Daminabo (2010), some of the climate change supportive administrative services include, integrating risk and hazard policies into school programme, creating alternative environment for recreation, adjustment in the school time table among others.

From the foregoing, it is obvious that instructional quality can be facilitated by the provision of these various forms of supportive administrative services by the school administrator. Akumah (2008) noted that the improvement of instruction depends on the ability of principals to perform those functions that would enhance teaching and learning. This entails that the activities of the school administrators are directed towards the primary responsibility of providing supportive administrative services needed to achieve the goals of instruction and ensure the delivery of quality education to the students.

School administrators have a direct role to play in the achievement of the aims and objective of secondary education this is because most secondary school policies are just on paper and needed to be properly implemented at the school level if the goals of education would be attained. However, it seems that there is a persistent decline in the quality of secondary school education in Nigeria.

In Anambra State personal observation of the researcher indicated that most secondary schools in the area are faced with many challenges. They are cases of truancy among teachers and students in the state. Some school teachers use the official school hours to sell their commodities such as cloths, bags, fairly used shoes or jewelries. Some attend to their shops during official hours.

Again, the northern part of the state experience adverse climate change and unfavourable environmental factors. Cases of floods as a result of rivers overflowing their banks are experienced in the area. In most cases, those displaced by the floods use the school premises as temporary accommodations in some occasions. In the affected areas, academic activities are truncated and most children, especially school children are exposed to extreme cold and unfourable weather. The students who were displaced by the flood victims had to remain at home till the flood subsides. This interruption in the school programme affects the students negatively. In the face of the above challenges, it is imperative to analyze the principals' supportive administrative services for teachers' effective classroom management. The dimensions of the problems in public and private schools in the state are also not known.

In the light of these scenarios, one may begin to ask if the principals are really living up to expectations in providing supportive administrative services towards helping the classroom teacher and the students alike to cope during such scenario. The problem of the study put in question form is: What are the climate change supportive administrative services supportive administrative services provided by principals for effective classroom management in public and private secondary school in Anambra State?

Purpose of the Study: The main purpose of this study is to analyse the climate change supportive administrative services provided by principals for effective classroom management in public and private secondary schools in Anambra State.

> Research Question: What are the climate change supportive administrative services by principals for effective classroom management in public and private secondary schools in Anambra State?

> Hypothesis: There is no significant difference in the mean response ratings of teachers in public and private secondary schools on climate change supportive administrative services provided by principals for effective classroom management in Anambra State.

\section{REVIEW OF RELATED LITERATURE}

\section{A. Supportive Administrative Services}

Different authors have defined the term, supportive administrative services in various ways. Drayer (2017) defined supportive administrative service as whatever it is that an individual receives for engaging in an activity that encourages him or her to increase his or her efficiency. For Adebanjo (2016) supportive administrative service is an effort made by organizations to recognize staff welfare, motivate job performance and boost productivity. According to Ademola (2015) supportive administrative services are the things given to workers to improve their services, merits, hard works and commitments. It includes a recompense made to or received by a staff for some favour, service or merit, or for hardship endured. Earlier, Akubue (2002), perceived supportive administrative service as management rewards and efforts by organizational management to attract, retain and motivate staff. Continuing, Akubue asserted that it encompasses all the tasks, activities duties and functions brought to support staff related assignments like recruitment, job analysis, compensation, performance training and staff development. 
Expatiating on the concept of supportive administrative service Akubue described it as those actions which educational administrators initiate to ensure that teachers' performance is monitored, welfare provided and that teachers are properly motivated to be productive. For Jones, and Jones (2012) providing supportive administrative services to teachers involve giving them support supervision, providing them with rewards, considering their welfare, providing in-service education, and promoting them as at when due. This agrees with Akubue (2002) who observed that supportive administrative services include providing an enabling organizational climate, improving staff behaviour through performance management, managing rewards, application of supportive supervision, counselling employees and organizational career planning.

From the above expository, the researcher conceptualizes supportive administrative services to include all the enabling conditions put in place to foster teacher's morale, commitment and professional development. Supportive administrative service as represented in this study is therefore taken to reflect on motivation, environmental friendliness, teachers and students welfare or reinforcement as rewards to teachers and students in the secondary school system.

\section{B. Climate Change Supportive Administrative Services}

The term, 'climate change supportive administrative services' include all the management services rendered by the principal to the teachers to enable them handle adverse alteration in existing weather condition over a period of time attributed mainly to greenhouse gas emissions and other causes. The manifestation of this change can be seen in the ecology, rainfall pattern, temperature and humidity (Adedoyin, 2010). Adverse climate change are inimical to the effective functioning of the school system at large, they are potential impediments to the classroom teachinglearning process. Classroom management in climate change therefore refers to the process of getting teaching and learning activities accomplished while facing climatic change problems. It therefore becomes necessary that principals provide supportive administrative services in times of climate change for teachers to ensure effective classroom management during such conditions. They must be able to introduce procedures, which will help teachers identify children who require particular supportive treatment relating to hunger, stress, sickness etc while in class. This places on the school managers the extra responsibility of coming to the aid of the teacher by providing certain services that will make the teacher to be more productive. Such supportive administrative service according to Adiele, Chukwuma and Daminabo (2010) include:

$>$ Integrating risk and hazard policies into School Programme: while in school, children are bound to face certain climate imposed risk and hazards. The school managers should be able to provide supportive administrative services that will ensure that children of different ages in school who are vulnerable to risk and hazards arising from climate change are adequately catered for without compromising classroom activities, decision, and daily routine. In specific terms, there will be need for a school re-adjustment in school programme to accommodate measures that will address health, emotional, and stress related issues arising from climate change. There will be need for measures to handle hunger, (through feeding), cold and hot weather (through appropriate school wears) etc. There should be preventive health care and hazard handling measures put place. These service are important because as rightly observed by Amakiri (2010), when health is compromised, children are more likely to suffer the long term effect and its consequences on classroom activities is better imagined.

$>$ Alternative Environment for Recreation: Climate change will cause sentimental hazards, which will have the tendency of reducing children's routine classroom and outdoor activities. Since growing children equally need outdoor activities for stability and optimal development, it is important that school manager's device supportive mechanism that will ensure that children outdoor spaces for play and recreation are not compromised. Measures aimed at reducing potential disasters are also important. For example, there should be adequate drainage in around school environment, proper waste management and proper sanitation.

$>$ Adjustment in school Time -Table: School time table remains the mechanism through which the various resources in the school such as teachers, students, teaching spaces, equipment and subjects are controlled, organized and optimally managed (Peter \& Harry cited in Akubue, 2002). Conventionally, the average school hours last for about 8 hours, from about 7 .30am $2,30 \mathrm{pm}$ in typical secondary school in Nigeria. This period is meant to accommodate both classroom activities and outdoor activities such as games, sports, recreation, labour among others. Extreme weather conditions caused by Climate change will definitely affect and cause the school timetable to be altered. This will have undesirable impact on teachers and the students if not properly managed. School administrators should anticipate such problems and adopt measures that will regulate and allocate more time to take care of losses. There will be need to provide policies that will ensure:

- Flexibility in school Timetable: As a matter of administrative policy, school timetable should be made flexible to allow extra time to cover grounds lost as a result of disruption caused by extreme weather conditions. There should be a policy directive to the effect that all teachers must abide and comply to changes in time frame when the need arises.

- Subject Allocation: Subject allocations on timetable should reflect the prevailing weather condition. Sciences should be reserved for early hours, while outdoor games and sports should not be under very hot and harsh weather.

- Prolong school hours based on the dictate of weather: If the weather does not permit the students to go home after the closing hours, they should be engaged in the school by the teachers. 
- School administration as a matter of policy ensure that children bring food to school to avoid hunger if the time overlaps

- Develop new rules that will take care of variety of situations that will arise due to extreme weather conditions, for example, rules about leaving the school during heavy rain and thunderstorm, flooding, cold etc.

$>$ Regularity of Teachers: The average teacher will like to put in minimum effort and yet expect maximum pay. Extreme weather conditions will therefore provide them enough room to give excuses. School administrators should anticipate this and adequately provide supervisory techniques that will ensure that teachers are constantly supervised and monitored when such events occur. This will checkmate those who have such tendency and stop them from drifting into selfcomplacency blaming the weather for their shortcomings. When teacher's truancy becomes a common feature, the students will be conditioned to adopting a posture of behaviour similar to those of their teachers (Akanubu, 1991). Such situations if not checked through supervision would amount to academic wastage and teachers' work out put will be seriously affected. It is therefore suggested that school administrators should device administrative procedures that will ensure that teachers are regular and consistent with their job in extreme weather situations. Where such is not possible due to justifiable reasons, the school must device means whereby such teacher makes up for the lost ground.

$>$ Effective Monitoring: Supportive administrative services must include a number of monitoring devices to effectively control the teachers. Disruptions caused by extreme weather conditions will trigger off certain undesirable habits from teachers, which if not properly checked, could be embarrassing and capable of disrupting classroom activities. Such habits include loitering, noise making, standing in clusters, unruly behaviour etc. School administrators must envisage this and device means of nipping it in the bud. This can be managed through the following techniques:

- Classroom Monitoring; teachers can be controlled by having them follow the scheme of work that must be covered weekly, monthly and termly. School administrators must ensure that they monitor the actual work covered, check staff attendance on daily basis and regulate the time for change of lessons. When teachers classroom activities are monitored and controlled, students will be forced to remain in class and learn.

- School fencing: Extreme weather condition may prompt teachers and students to leave school at the slightest opportunity before the normal school closing hour. To check this, the school premises should be fenced. There should be clear instructions on when to enter or leave the school premises. Those that man the gate must be under serious instruction not to allow people leave before closing time. The school authority should not accept anything less than compliances from security men. Appropriate disciplinary measures must be taken promptly on those who fail to comply with laid down rules.
Secondary school principals should endeavour to provide these climate change supportive administrative services as it will go a long way in helping classroom teachers in the management of classrooms in the face of climate change. This is owed to the fact that the school is a system, what affects an integral aspect of a school affects the entire school system.

Environmental Supportive Administrative Services: A substantial body of research shows that a school environment has broad influence on students' learning and growth. When students find their environment to be supportive and caring, they are less likely to become involve in substance abuse, violence and other problem behaviours in the classroom (Daminabo, 2010), and they are more likely to develop positive attitudes toward themselves and prosocial attitudes and behaviours toward others (Akiri, 2008). Olawolu and Okejim (2010) posited that school environment embraces recreational facilities, school buildings, interior provisions such as ventilation, furniture (seats and sitting arrangements) and other provisions that can contribute to learning such as landscaping of the school, canteen services, toilet facilities among others. Ezewu (199o) cited in Azu (2003) defined school environment as the totality of the activities and conditions, which a group of people within the same geographical location are subjected to. He maintained further that school environment include all the factors existing in a school both physically, administratively, or psychological which influence the achievement of teachers, non-teaching staff and students of that school.

Conducive school environment foster positive outcome by promoting students' sense of connectedness, belongingness and community during the school day (Akuma, 2008). Connectedness, belongingness and community all refer to students' sense of being close, respectful relationships with peers and staff at school. Amakiri (2010) maintained that quality education to a large extent depends on the learning environment. He argued that students educated in schools equipped with equipment and facilities such as laboratories, workshops, libraries, books, teaching aids among others will no doubt perform better than their counterparts in an opposite environment. Amakiri, (2010) posits that a difficult and demanding job of teaching and learning (including classroom management) can be made more pleasant if the teacher is allowed to work in aesthetically pleasant environment.

Environmental factors such as temperature, light, colour, sound absorption, ventilation and spatial arrangement can either facilitate or hinder a teacher in carrying out his classroom management job (Amakiri, 2010). Edward (2010) opined that for education in school to be effective, the environment needs to be conducive for learning, allowing the students space and time to interact within the teaching and learning process. Secondary school administrators in the bid to ensure effective classroom management should provide environmental supportive administrative services. Such services include the following: 
Proper Storage of Classroom Resources: it is necessary that teachers be sufficiently provided with supportive administrative services that will ensure that equipment for use in the classroom are not unnecessarily exposed to sun or rain. Under extreme conditions of rain or hot weather, some equipment are likely to expand or contract, also some wax and grease used to hold some wires might melt. This may cause damage to the equipment. For example class equipment such as public address system might be damaged when exposed to direct sun-light or rain. This will affect classroom management adversely as the teacher with large class size may not be able to control the classroom without the public address system. It is therefore necessary for school administrators to provide support staff whose duty is to keep these equipment in cool dry places.

Class Control and Sitting Arrangement: some classroom factors such as illumination, aeration among others cannot be manipulated by the classroom teachers and therefore should be adequately considered and addressed by school managers. Apart from allocating an average of 40 students per class, school management should ensure that classrooms have proper lighting, proper ventilation, and not more than two students per desk and use appropriate colour for the painting and decoration of classroom walls. School managers should as well ensure that wiring of school buildings and classrooms are not carelessly done. Other environmental supportive administrative services that the school administrators can provide for effective classroom management according to Adiele, Chukwuma and Daminabo (2010) include the following:

- Beautification and planting of trees and flowers on school compound

- Provision of waste baskets at strategic positions on school compound

- Maintenance, repair and replacement of worn-out games and sport facilities

- Constant repair of school building
From the foregoing, one can categorically conclude that the school environment as it were can to a great extent affect classroom management. Principals are therefore expected to provide environmental supportive administrative services that will enhance teachers' effective classroom management. At this juncture, it is important to discuss the dimensions of supportive administrative services.

\section{RESEARCH METHOD}

The area of this study is Anambra state and the descriptive survey research design was used. There are six education zones namely Aguata, Awka, Nnewi, Ogidi, Onitsha, and Otuocha education zones. The population for this study comprised 15,990 respondents made up of 6,293 teachers in the 256 public secondary schools and 9,697 teachers in the 481 registered private secondary schools in Anambra state. The sample size for this study is 852 teachers. The instrument for data collection is a structured questionnaire. The instrument was structured on a 4-point scale of "Strongly Agree $(\mathrm{SA}=4)$, Agree $(\mathrm{A}=3)$, Disagree $(\mathrm{D}=2)$ and Strongly Disagree $(\mathrm{SD}=1)$ " response pattern. The questionnaire was subjected to face validation using three experts who are lecturers. The reliability of the instrument was established using 100 teachers (50 in private secondary schools and 50 in public secondary schools) in 20 secondary schools in Enugu state. Cronbach alpha method was used to determine reliability of the items because the instrument is homogeneously structured. The reliability coefficient of the instrument was 0.74 .

The instrument was administered on the respondents directly by the researchers with the help of eight research assistants who are teachers in the various schools sampled. All the 852 copies of the questionnaire were correctly filled and retrieved. They were collated and subjected to statistical analysis. Data collected were analyzed using mean ratings to answer the research questions and t- test to test the hypotheses at 0.05 level of significance.

\section{PRESENTATION OF RESULTS}

> Research Question: What are the climate change supportive administrative services by principals for effective classroom management in public and private secondary schools in Anambra State?

\begin{tabular}{|c|c|c|c|c|c|c|c|}
\hline S/N & \multicolumn{3}{|c|}{ Public Sec. Schools } & \multicolumn{3}{|c|}{ Private Sec. Schools } \\
\cline { 3 - 7 } & & $\overline{\boldsymbol{X}}$ & SD & Rmk & $\overline{\boldsymbol{X}}$ & SD & Rmk \\
\hline 1 & Tree planting around the school premises & 2.67 & .91 & $\mathrm{~A}$ & 2.87 & .91 & $\mathrm{~A}$ \\
\hline 2 & $\begin{array}{c}\text { Making sure that classroom roofs are well sealed to avoid water } \\
\text { leakages inside the classroom during rainfall }\end{array}$ & 2.97 & .94 & $\mathrm{~A}$ & 2.61 & .96 & $\mathrm{~A}$ \\
& Making sure that classroom are well ventilated & 3.13 & .89 & $\mathrm{~A}$ & 2.44 & .89 & $\mathrm{D}$ \\
\hline 3 & Special school wear during extreme cold weather & 2.44 & .89 & $\mathrm{D}$ & 3.12 & .74 & $\mathrm{~A}$ \\
\hline 4 & Special school wear for hot weather & 3.11 & .77 & $\mathrm{~A}$ & 3.15 & .67 & $\mathrm{~A}$ \\
\hline 5 & Adequate drainage in the school & 2.64 & .89 & $\mathrm{~A}$ & 2.44 & .90 & $\mathrm{D}$ \\
\hline 6 & Adequate waste management in the school & 2.68 & .84 & $\mathrm{~A}$ & 2.50 & .81 & $\mathrm{~A}$ \\
\hline 7 & Proper sanitation & 2.03 & .62 & $\mathrm{D}$ & 3.33 & .53 & $\mathrm{~A}$ \\
\hline 8 & School hours based on the dictate of the weather & 2.15 & .90 & $\mathrm{D}$ & 3.15 & .75 & $\mathrm{~A}$ \\
\hline 9 & Provision for feeding for the students to avoid hunger if time \\
overlaps as a result of climate change & 3.06 & .90 & $\mathrm{~A}$ & 2.86 & .75 & $\mathrm{~A}$ \\
\hline 10 & & & & & & & \\
\hline
\end{tabular}


ISSN No:-2456-2165

\begin{tabular}{|c|c|c|c|c|c|c|c|}
\hline 11 & $\begin{array}{c}\text { Rules that will take care of variety of situations that will arise due } \\
\text { to extreme weather conditions }\end{array}$ & 3.26 & .61 & $\mathrm{~A}$ & 3.27 & .52 & $\mathrm{~A}$ \\
\hline 12 & $\begin{array}{c}\text { Fencing the school wall to avoid students moving out from school } \\
\text { during extreme weather conditions like heavy rainfall }\end{array}$ & 2.71 & .91 & $\mathrm{~A}$ & 3.17 & .76 & $\mathrm{~A}$ \\
\hline 13 & $\begin{array}{c}\text { Hiring of security men to make sure students do not leave the } \\
\text { school during extreme weather condition like heavy rainfall. }\end{array}$ & 3.13 & .81 & $\mathrm{~A}$ & 3.20 & .64 & $\mathrm{~A}$ \\
\hline & Mean of means & $\mathbf{2 . 7 7}$ & $\mathbf{0 . 7 7}$ & $\mathbf{A}$ & $\mathbf{2 . 9 3}$ & $\mathbf{0 . 7 6}$ & $\mathbf{A}$ \\
\hline
\end{tabular}

Table 1:- Mean Ratings and SD of Respondents on Climate Change Supportive Administrative Services provided by Principals for Effective Classroom Management in Public and Private Secondary Schools in Anambra State.

As shown in Table 1, the mean ratings of the respondents in public and private secondary schools for items $1,2,5,7,10,11,12$ and 13 ranges between 2.50 and 3.27 and fall within the range for agree in the decision rule. This means that the respondents agree on those items. The respondents in public secondary schools disagree on issues raised in items 4,8 and 9 as indicated in the mean ratings of $2.44 ; 2.03$ and 2.15 respectively. The respondents in the private secondary schools also disagree on issues raised in items 3 and 6 as indicated by the mean ratings of 2.44 for each of them.

Again, the standard deviations for the respondents in public secondary schools range between 0.61 and 0.94 . In the same vein, the standard deviations for the respondents in private secondary schools range between 0.64 and 0.96 .
The size of the scores is not large and indicates small variations in the mean ratings of the respondents.

The mean of means of the respondents in public secondary schools is 2.77 with 0.77 as standard deviations. Again, the mean of means of the respondents in private secondary schools is 2.93 with standard deviations of 0.76 . The mean of means indicate agreement but there are items such as 3,4, 6,8 and 9 where the respondents disagree.

Test of Hypothesis: There is no significant difference in the mean response ratings of teachers in public and private secondary schools on climate change supportive administrative services provided by principals for effective classroom management in Anambra State.

\begin{tabular}{|c|c|c|c|c|c|c|c|}
\hline Group & $\begin{array}{c}\text { Sample } \\
\text { Size }\end{array}$ & $\bar{X}$ & SD. & df. & t-Cal. & t-Crit. & Decision \\
\hline Public & 341 & 2.77 & 0.77 & \multirow[b]{2}{*}{850} & \multirow[b]{2}{*}{-0.29} & \multirow[b]{2}{*}{ \pm 1.9650} & \multirow{2}{*}{$\begin{array}{c}\text { Not } \\
\text { Significant (NS) }\end{array}$} \\
\hline Private & 511 & 2.93 & 0.76 & & & & \\
\hline
\end{tabular}

Table 2:- t-test Comparison of Mean Ratings on Climate Change Supportive Administrative Services Provided by Principals for Effective Classroom Management in Public and Private Secondary Schools in Anambra State.

In Table 2, the result showed that, t-test calculated is 0.29 , while the t-test critical table value is \pm 1.9650 . This value calculated is less than the critical observed table value which is \pm 1.9650 and falls within the acceptable region. The null hypothesis $\left(\mathrm{H}_{0}\right)$ of no significant difference in the mean ratings is thus accepted indicating that there is no significant difference in the mean ratings of public and private school teachers on the climate change supportive administrative services provided by principals for effective classroom management in public and private secondary schools in Anambra State.

\section{Summary of Findings}

Based on the data analysis, the summary of major findings are as follows:

- In public secondary schools, special school wears during extreme cold weather, proper sanitation and basing school hours on the dictates of the weather, are not provided as part of climate change supportive administrative services for classroom management.

- In the private secondary schools, proper ventilation of classrooms and adequate drainage systems are not provided as part of climate change supportive administrative services for effective classroom management.
- In public secondary schools, adequate workshops are not provided as part of environmental supportive administrative services for effective classroom management.

- There is no significant difference in the mean ratings of teachers in public and private secondary schools on the climate change supportive administrative services provided by principals for effective classroom management in Anambra state.

\section{DISCUSSION OF RESULTS}

Results in table 1 indicated that public secondary school principals do not provide special school wears during extreme cold weather. Again, they do not provide proper sanitation in their schools nor base school hours on the dictates of the weather. The inability of the public secondary school principals to provide the above climate change supportive administrative services for effective classroom management could be attributed to the nature of their job. They are government's agents implementing the programmes and policies of their employers. The government has official school hours which the principals cannot change. Again, provision of special school wears for students might either be abused by principals or interpreted 
by parents and guardians as extortions of the students. The expected role of the principals in this regard is therefore advisory. Parents and government need to be properly informed of the adverse effects of unfavourable weather. The above notwithstanding, proper sanitation exercise is important for the wellbeing of both staff and students. If this is not done in the schools, there will be outbreak of diseases in the school.

The findings of this study agree with Sowell (2013) who found that students that he studied were provided with proper sanitation practices that made them healthier and performed better academically than their counterparts who were not provided with proper sanitation practices. Sowell findings indicated the relevance of sanitation to students' health and academic performance.

Further findings of the study indicated that private secondary school principals do not provide proper ventilation of classroom and adequate drainage systems as part of their climate change supportive administrative services for effective classroom management. Proper ventilation of classrooms and good drainage systems are very important for the health of both teachers and their students. In schools where these supportive administrative services are not provided, it is most likely that the health of the school inmates will be adversely affected. Since outbreak of diseases may result, it is most likely that the academic performance of the students might be affected negatively. The findings of this study agree with Iwuji (2014) who found that poor classroom ventilation and malfunctioning drainage systems are mostly problems facing effective classroom management.

Data analysis for hypothesis revealed that teachers in public and private secondary schools n Anambra state did not differ significantly in their mean ratings on the climate change supportive administrative services provided by principals for effective classroom management. The respondents in their mean ratings indicated that climate change supportive administrative services are provided in both public and private secondary schools in the area. They only rated a few items differently but the difference was not significant.

\section{CONCLUSION}

The conclusion is that both public and private secondary school principals in Anambra State provided supportive administrative services for effective classroom management but differ in some aspects. There are those provided in public secondary schools which are not provided in the private secondary schools. Again, there are those provided in private secondary schools but are not provided in the public secondary schools.

\section{RECOMMENDATIONS}

Based on the findings of this study recommendations are made as follows:

$>$ Public secondary school principals should not only maintain proper sanitation in their schools, they should encourage their students to wear jackets or sweaters on their school uniforms during extreme cold weather.

$>$ Again, private secondary school principals should not only ensure well ventilated classrooms, the drainage systems in the schools should also be functioning very well.

$>$ The government should not only organize workshops for secondary schools on climate change supportive administrative services, the private schools should be provided with waste collectors while the private schools should maintain the provided facilities.

\section{REFERENCES}

[1]. Adebanjo, D.O. (2016). Management approach to education. Lagos: Handikuch Books.

[2]. Adedoyin, S. F. (2010). Good governance: Implications for climate change, food security and rural development in Nigeria. Maiden edition of the Faculty of Agricultural sciences, public lecture series, University of Ado-Ekiti, Nigeria.

[3]. Ademola, L. A. (2015). Management support and the staff. Akure: Fagbanigbe Press.

[4]. Adiele, E. E., Chukwuma, C. C. \& Daminabo, D. A. F. (2010).Providing supportive administrative services for classroom management in climate change.In A. O Ayeni; U. G. Emetarom; S. O. Nwafor \& A. I. Atanda (Eds.). Educational management, environmental literacy and climate change. Ibadan, Nigeria: His Lineage Publishing House.

[5]. Adiele, O. Chukwuma, A.G. \& Daminabo, M. (2010). The mobilization and management of financial resources in Nigerian universities. Lagos: InterPrinters Ltd.

[6]. Ajayi, A. I. (2010). Teacher and classroom management with respect to climate change. In A. O Ayeni; U. G. Emetarom; S. O. Nwafor and A. I. Atanda (Eds.). Educational management, environmental literacy and climate change. Ibadan, Nigeria: His Lineage Publishing House.

[7]. Akiri, O. (2008). Management problems militating against secondary school teachers' effective in Calabar metropolis. Unpublished Masters. Thesis, University of Port Harcourt.

[8]. Akubuo, C. (2002). The Nigerian teacher and nation building. Nigerian Journal of Curriculum and Instruction. 10, (5), 23-26.

[9]. Akuma, A. (2008). An introduction to classroom management. Enugu: Dispense Publishers. 
[10]. Amakiri, A. A. D. (2010). The secondary school teacher and clsassroom management in climate change. In A. O Ayeni; U. G. Emetarom; S. O. Nwafor and A. I. Atanda (Eds.). Educational management, environmental literacy and climate change. Ibadan, Nigeria: His Lineage Publishing House.

[11]. Azu, P. I. (2003). Classroom management and school organization.Owerri: Polytechnic publishers.

[12]. Daminabo, S. F. (2010). Good governance: implications for climate change, food security and rural development in Nigeria. Maiden edition of the faculty of Agricultural sciences, public lecture series, University of Ado-Ekiti, Nigeria.

[13]. Drayer, L.N. (2017). Management support of staff: A humanistic approach. California: Eagle Wood Cliffs.

[14]. Edwards, C. (2017). Classroom management and discipline, New York: Macmillan College.

[15]. Froyen, L. \& Ivertson, M. (1999).Classroom Management and Learnerse Achievement in Secondary Schools in Kitgum Town Council. Unpublished Dissertation submitted in Partial Fulfillment of the Requirements for the Award of the Degree of Master of Educational (Planning, Management and Administration) of Gulu University.

[16]. Iwuji, L. (2014). The problems of classroom management in secondary schools in Nigeria: Study of secondary schools in Owerri Municipal Council of Imo State. Unpublished Dissertation, Department of Education Foundation. University of Port Harcourt.

[17]. Jones, V. F., \& Jones, L.S. (2012). Comprehensive classroom management: Creating communities of support and solving problems. (10th edition). Prentice Hall.

[18]. Kyriacou, C.O. (2004). Effective Teaching in Schools. United Kingdom: Stanley Thorues Publishers Ltd.

[19]. Olawolu, O. E. \& Okejim, E. M. (2010). Teacher and classroom management in climate change. In A. O Ayeni; U. G. Emetarom; S. O. Nwafor and A. I. Atanda (Eds.). Educational management, environmental literacy and climate change. Ibadan, Nigeria: His Lineage Publishing House.

[20]. Sowell, C. H. (2013). Classroom management strategies: The impact on students' achievement. Unpublished dissertation, Liberty University, Lynchburg. 